\title{
Growth of Japanese Quail Chicks in Simulated Weightlessness
}

\author{
P. ŠKROBÁNEK, M. HRBATÁ, M. BARANOVSKÁ, M. JURÁNI \\ Institute of Animal Biochemistry and Genetics, Slovak Academy of Sciences, Ivanka pri Dunaji, \\ Slovak Republic \\ Received December 1, 2003 \\ Accepted June 17, 2004
}

\begin{abstract}
Škrobánek, P., M. Hrbatá, M. Baranovská, M. Juráni: Growth of Japanese Quail Chicks in Simulated Weightlessness. Acta Vet. Brno 73, 2004: 157-164.

Hypodynamy is a method to simulate weightlessness in the earth laboratory conditions. The objective of this study was to study the effects of hypodynamy on the growth of the body and of the right leg of female Japanese quail chicks reared under these conditions from day 2 after hatching to 56 days of age. Therefore, body weight, food consumption, food conversion and length of femur, tibiotarsus and tarsometatarsus of the quail chicks were recorded at weekly intervals.

The effect of hypodynamy on these indices was significant $(p<0.001)$. The mean body weight of the test group after the 56-day hypodynamy was about $34 \%$ less than that of the age-matched control. The food consumption in both groups increased with age but in the hypodynamy quails it was $17 \%$ lower compared to control. Similarly, the food conversion of test birds was affected until day 42 of age except for day 14 . The size of the femur in the hypodynamy group was reduced (by $0.7 \mathrm{~mm}$ ) compared to the age-matched control at 56 days. The tibiotarsus and tarsometatarsus of hypodynamy quails were shorter by $4.41 \mathrm{~mm}$ and $3.35 \mathrm{~mm}$, respectively, at the end of experiment.

Our results show that Japanese quail female chicks are capable to grow and develop under conditions of prolonged simulated weightlessness. Based on these results a similar experiment under conditions of real weightlessness in space may be considered.
\end{abstract}

Hypodynamy, body weight, food conversion, femur, tibiotarsus, tarsometatarsus

In the future long term space missions, Japanese quail could be used as a high quality protein food source (meat and eggs). To reach this goal, a detailed understanding of embryogenesis, post-hatching development and adult life of these birds will be required. So far some experiments have been carried our showing that embryogenesis of Japanese quail is possible in conditions of weightlessness (microgravity) without serious difficulties (Gurye va et al. 1993). However, only a few studies have examined the effects of altered gravity on quail posthatching development. In experiments aboard the MIR space station, Japanese quail were exposed to microgravity for 4 - 5 days (Boda et al. 1992; Sabo et al. 2001). How microgravity may influence further development of quail chicks is unknown. A partial answer may be obtained in ground-based animal models of simulated microgravity. According to Pozsgai et al. (1990) hypodynamy is the most suitable method of simulating weightlessness conditions. The first experiments with hypodynamy in birds were carried out in the adult Japanese quails (Juráni et al. 1983). Later, in another experiment the effects of hypodynamy on live body mass, food conversion and egg laying were investigated ( $\mathrm{S}$ abo et al. 1998). However, there are only scarce data on survival and development of Japanese quail chicks in conditions of hypodynamy (Šk krobánek et al. 2001; Škrobánek and Hrančová 2003).

Growth is the most studied factor to estimate postembryonic development of an individual (Ricklefs 1979; Lilja 1983). Therefore, the aim of this study was to study the effects of simulated microgravity (hypodynamy) on the overall growth and growth of the right leg of Japanese quail chicks reared under hypodynamy from day 2 after hatching to 56 days of age.

\footnotetext{
Address for correspondence:

Ing. Peter Škrobánek, CSc.

Institute of Animal Biochemistry and Genetics

Slovak Academy of Sciences

Moyzesova 61, 90028 Ivanka pri Dunaji

Slovak Republic
}

\author{
Phone: + 4210245943881 \\ Fax: + 4210245943932 \\ E-mail: ubgzskro@savba.sk \\ http://www.vfu.cz/acta-vet/actavet.htm
}




\section{Materials and Methods}

Sixty-eight female newly-hatched Japanese quail chicks (Laying Line 01 Ivanka pri Dunaji), mean body weight $7.46 \pm 0.62 \mathrm{~g}$, were used in the present study. On the second day after hatching, forty-eight chicks (test group) were exposed to hypodynamy. Hypodynamy is a simulation of weightlessness where quails are placed in individual slings suspended by a flexible metal device such that their legs cannot touch the floor. However, chicks may move about freely by moving their wings. The size of the slings was enlarged at 7, 14, 21, 28 and 35 days of age (from $4 \mathrm{~cm} \times 3 \mathrm{~cm}$ to $5 \mathrm{~cm} \times 4 \mathrm{~cm}$ to $6 \mathrm{~cm} \times 5 \mathrm{~cm}$ to $7 \mathrm{~cm} \times 6 \mathrm{~cm}$ and to $8 \mathrm{~cm} \times 7 \mathrm{~cm}$ ) to accommodate the growth of the quail. The exchange of the smaller sling size for the larger one took approximately 15 seconds. Birds showing hyperactivity, escape attempts, turning $180^{\circ}$ in the sling, soaking in the water from the drinker, as well as those showing total apathy, at least three times per day were eliminated from experiment. The quail behaviour was monitored daily at five two-hour intervals. At the same time, twenty quail chicks (control group) were placed in rearing box $(1.2 \times 0.6 \times 0.3 \mathrm{~m})$. The birds of test and control groups were kept in the respective conditions until 56 days of age in a windowless poultry room with controlled ventilation and electrical heating by infrared lamps. The temperature was adjusted from $35-36^{\circ} \mathrm{C}$ for the first few days after hatching to about $20^{\circ} \mathrm{C}$ at 4 weeks and remained at this level until the end of the experiment. A commercial starter mash HYD-13 and water were available ad libitum. The diet was granular and contained $260 \mathrm{~g} / \mathrm{kg}$ protein and $11.5 \mathrm{MJ}$ metabolisable energy/ $\mathrm{kg}$. The lighting in the rearing room was left on continuously. The care and use of animals were in accordance with laws and regulations of the Slovak Republic and were approved by the Ethical Committee of the Institute of Animal Biochemistry and Genetics of Ivanka pri Dunaji.

Individual body weight of the quail chicks was recorded at the beginning of the experiment and the chicks were individually weighed at weekly intervals until they were 8 weeks old. Similarly, food consumption and length of femur, tibiotarsus and tarsometatarsus of right leg were recorded for test and control group on a weekly basis. Food conversion values ( $\mathrm{g}$ food/g body weight gain) were determined at each weighing period. Their growth rate was evaluated by the average daily body weight gain $(\mathrm{g})$. The relative growth rate of femur (tibiotarsus, tarsometatarsus) was expressed as ratio of week length gain to its previous total length. Means and standard deviations were calculated from individual values using standard procedures. Statistical comparisons between the overall mean values for test and control group were made using Student's $t$-test.

Table 1

Body weight, food consumption and food conversion of Japanese quail female chicks exposed to hypodynamy

\begin{tabular}{|c|c|c|c|c|c|c|}
\hline \multirow{2}{*}{$\begin{array}{c}\text { Age } \\
\text { (days) }\end{array}$} & \multicolumn{2}{|c|}{$\begin{array}{c}\text { Body weight } \\
(\mathrm{g})\end{array}$} & \multicolumn{2}{c|}{$\begin{array}{c}\text { Food consumption } \\
\text { (g/bird/day) }\end{array}$} & \multicolumn{2}{c|}{$\begin{array}{c}\text { Food conversion } \\
\text { (g food/g gain) }\end{array}$} \\
\cline { 2 - 7 } & $\mathrm{H}$ & $\mathrm{C}$ & $\mathrm{H}$ & $\mathrm{C}$ & $\mathrm{H}$ & $\mathrm{C}$ \\
\hline 1 & 7.46 & 7.46 & - & - & - & - \\
7 & $14.98^{+++}$ & 19.61 & $3.05^{+++}$ & 3.46 & 2.85 & 1.99 \\
14 & $30.57^{+++}$ & 42.91 & $3.55^{+++}$ & 6.68 & 1.59 & 2.01 \\
21 & $47.05^{+++}$ & 72.14 & $10.83^{+++}$ & 11.59 & 4.59 & 2.77 \\
28 & $63.38^{+++}$ & 98.76 & $12.22^{+++}$ & 13.21 & 5.24 & 3.48 \\
35 & $76.04^{+++}$ & 119.13 & $14.06^{+++}$ & 18.56 & 7.77 & 6.38 \\
42 & $88.75^{+++}$ & 142.75 & $16.87^{+++}$ & 18.87 & 9.27 & 5.60 \\
49 & $98.00^{+++}$ & 151.00 & $17.30^{+++}$ & 19.46 & 13.11 & 16.49 \\
56 & $105.21^{+++}$ & 158.63 & $20.42^{+++}$ & 24.40 & 19.83 & 22.39 \\
\hline
\end{tabular}

${ }^{+++} p<0.001$

$\mathrm{H}$ - hypodynamy, $\mathrm{C}$ - control

\section{Results}

Mean body weight in both groups increased gradually until 56 days of age (Table 1). However, the body weight gain in the hypodynamy group was markedly decreased compared to that of control. The mean body weight of test quail after 56-day hypodynamy was about $34 \%$ less than that of the age-matched control $(p<0.001)$. A marked body weight gain was seen in the control quail until the 42 day of age (Fig. 1). The maximum body weight gains were achieved between 21 to 28 days of age. The same trend was observed for food consumption and food conversion. Food consumption in both groups increased with age but 


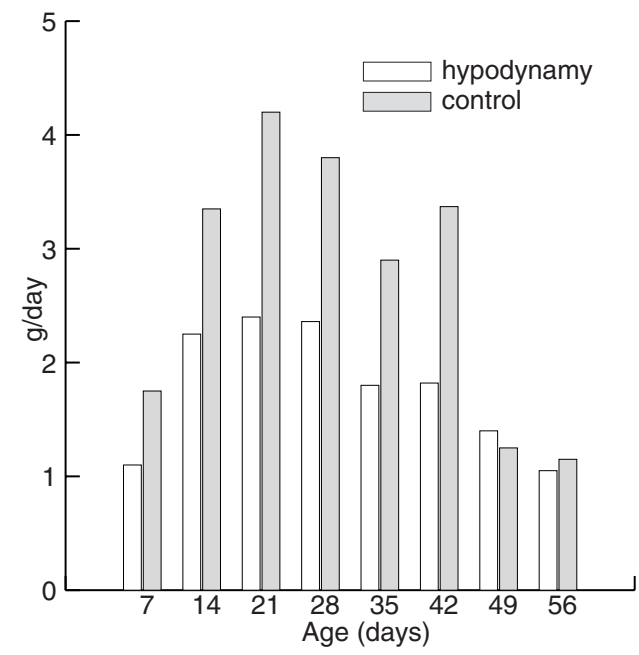

Fig.1. Mean body weight gain in hypodynamy and control group of Japanese quail females

it was about $17 \%$ lower in the hypodynamy quails than that of control. Also, the food conversion values of test birds were affected until the 42 days of age except for day 14 .

The actual size of the femur in the hypodynamy group, as well as control, gradually increased following the growth (Table 2). However, the size of femur of hypodynamy quails was significantly smaller than that of control already on day $7(p<0.001)$. The maximum differences in femur size were observed on days 21 and 28. After day 42 until the end of the experiment, there were minimum differences in the femur size between hypodynamy and control group. The femur size in the hypodynamy group was less (by $0.7 \mathrm{~mm}$ ) than that found in the age-matched control at 56 days.

A maximum for the relative femur growth rate of hypodynamy and control group was recorded from hatching to 7 days (Fig. 2). Towards the end of the experiment, the relative

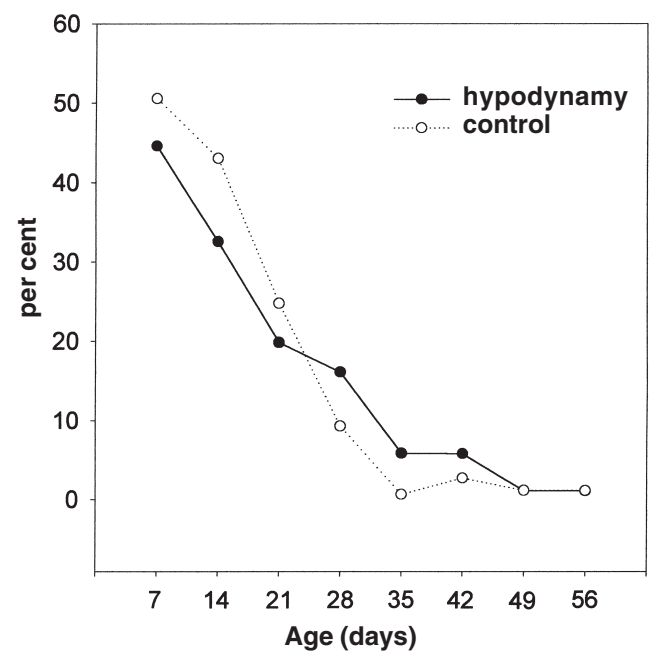

Fig.2. Relative femur growth rate 
femur growth rate decreased. The lower relative femur growth rate of hypodynamy group to 21 days of age was partially compensated for by a higher growth rate between 28 and 42 days of age compared to control. At 49 and 56 days of age, the relative femur growth rate of hypodynamy and control quails was nearly identical.

Table 2

Length of femur, tibiotarsus and tarsometatarsus of Japanese quail right leg

\begin{tabular}{|c|c|c|c|c|c|c|}
\hline \multirow{2}{*}{$\begin{array}{c}\text { Age } \\
\text { (days) }\end{array}$} & \multicolumn{2}{|c|}{$\begin{array}{c}\text { Femur } \\
(\mathrm{mm})\end{array}$} & \multicolumn{2}{c|}{$\begin{array}{c}\text { Tibiotarsus } \\
(\mathrm{mm})\end{array}$} & \multicolumn{2}{c|}{$\begin{array}{c}\text { Tarsometatarsus } \\
(\mathrm{mm})\end{array}$} \\
\cline { 2 - 7 } & $\mathrm{H}$ & $\mathrm{C}$ & $\mathrm{H}$ & $\mathrm{C}$ & $\mathrm{H}$ & $\mathrm{C}$ \\
\hline 1 & 14.39 & 14.39 & 19.76 & 19.76 & 15.34 & 15.34 \\
7 & $20.81^{+}$ & 21.67 & $26.26^{+++}$ & 27.87 & $18.81^{+++}$ & 21.70 \\
14 & $27.59^{+++}$ & 31.00 & $33.35^{+++}$ & 37.82 & $23.47^{+++}$ & 28.57 \\
21 & $33.07^{+++}$ & 38.68 & $39.53^{+++}$ & 47.36 & $26.97^{+++}$ & 33.04 \\
28 & $38.41^{+++}$ & 42.29 & $45.17^{+++}$ & 52.33 & $29.97^{+++}$ & 33.83 \\
35 & $40.67^{+++}$ & 42.58 & $48.46^{+++}$ & 54.08 & $30.79^{+++}$ & 34.88 \\
42 & $43.04^{+++}$ & 43.75 & $49.29^{+++}$ & 54.21 & $31.17^{+++}$ & 34.96 \\
49 & $43.55^{+++}$ & 44.27 & $49.57^{+++}$ & 54.23 & $31.64^{+++}$ & 35.21 \\
56 & $44.05^{+++}$ & 44.79 & $49.84^{+++}$ & 54.25 & $32.11^{+++}$ & 35.46 \\
\hline
\end{tabular}

${ }^{+} p<0.05,{ }^{+++} p<0.001$

$\mathrm{H}$ - hypodynamy, $\mathrm{C}$ - control

The growth rates of tibiotarsus and tarsometatarsus were similar compared to the thigh growth rate (Table 2). As early as after the first 7 days, the tibiotarsus and tarsometatarsus length values of hypodynamy and control quail changed significantly. At 21 days of age, these differences reached maximum values between treatment groups. The birds exposed to hypodynamy had shorter tibiotarsus (on average by $7.83 \mathrm{~mm}$ ) and tarsometatarsus (by $6.07 \mathrm{~mm}$ ) than controls. During the next days of hypodynamy, the length differences between the test and control group were significantly smaller, however, they were maintained to the end of experiment. The tibiotarsus and tarsometatarsus of hypodynamy quails were shorter by about $4.41 \mathrm{~mm}$ and $3.35 \mathrm{~mm}$, respectively.

The relative tibiotarsus growth rate of test and control group was very similar to the relative femur growth rate (Fig. 3). The tibiotarsus growth decreased gradually until the end

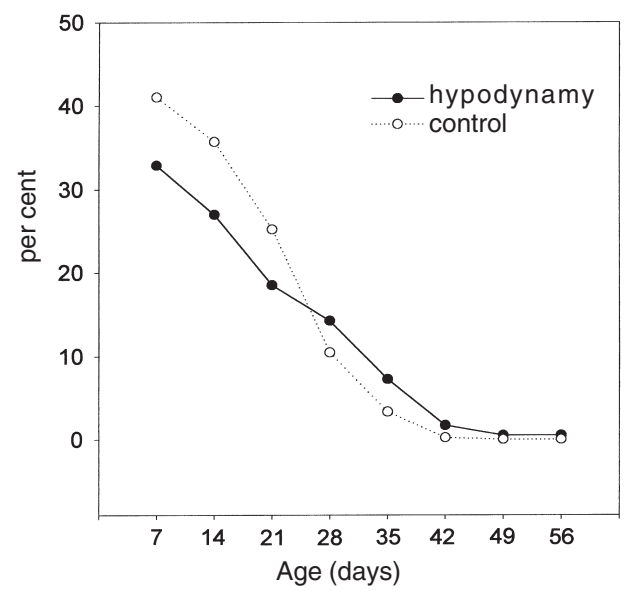

Fig. 3. Relative tibiotarsus growth rate 
of the experiment. However, tibiotarsus growth rate in hypodynamy group compared with control was higher from day 28 to day 56 of age.

The mean growth intensity of tarsometatarsus had a more fluctuating course than that of the femur and tibiotarsus (Table 2). The highest relative tarsometatarsus growth rate of control group was recorded after hatching (Fig. 4). Thereafter, it decreased although it slightly increased again on days 35 and 49 of age. The relative tarsometatarsus growth rate of hypodynamy group reached a maximum on day 14 of age. From this moment on it gradually decreased until day 42 and increased again at day 49 of age. The growth rate of tarsometatarsus in both groups was similar on day 21 of age.

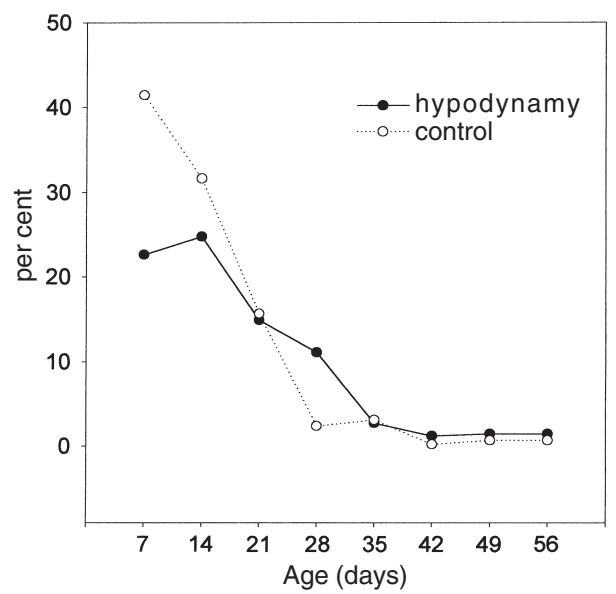

Fig. 4. Relative tarsometatarsus growth rate

\section{Discussion}

There are many studies that characterize the postincubation growth and development of Japanese quail chicks under standard earth rearing conditions. For example, no relationship was indicated between embryo wet weight at 12 days of incubation and posthatching weight in quail (Ali and Godfrey 1970). It was observed that heavier quails at hatching were also heavier at reaching a mature body weight (Laskey and Edens 1985). The increased growth rate after hatching of selected quail is accompanied by a more rapid early development of digestive organs (Lilja and Marks 1991). Since the increase in growth rate is linked to an increase in the relative size of the digestive organs, the growth rate is most likely restricted by the capacity to ingest and digest food (Lilja et al. 1985). Moreover, the pattern of organ growth of the quail is characterised by a rapid early development of wings, pectorals and feathers (Lilja 1982). The maximum relative growth rate of divergent and control quail lines was observed during the first week of age (Ag g re y 2003). The Japanese quail selected for high relative weight gain started to utilise food more efficiently than the quail line selected for low relative weight gain as early as 10 to 14 day, that is, at the age when their relative growth rate first became greater (Hyánková et al. 2001). Similarly, when quail lines previously selected for high 4-week body weight were fed a $28 \%$ protein diet the age at maximum growth was 4 to 6 days earlier than the corresponding age of controls (Marks 1978).

The present study provides the first partial characterization of overall body growth and growth of the right leg of Japanese quail female chicks exposed to simulated weightlessness conditions from hatchling to maturity. The results demonstrated that 
hypodynamy had a profound influence on the measured parameters. Lower body weight, food consumption and food conversion was observed throughout this study in the hypodynamy group. Moreover, the lengths of femur, tibiotarsus and tarsometatarsus of quail right leg were significantly reduced as early as after 7 days of non-functioning than in the age-matched control. However, this was not entirely unexpected, since simulated microgravity (hypodynamy) and weightlessness are known to be stressful factors. It was reported that periosteal bone formation and tubular bone growth was gradually decreased during the 33-day hypodynamy in legs of adult Japanese quails (Guryeva et al. 1998). Simulated microgravity induced also morphological differences of their striated musculature (Kočišová et al. 1998). Sabo et al. (1998) report that adult Japanese quail under 84 -days hypodynamy decreased their body weight by about $14 \%$. Similar responses were observed in adult quail after 7-day exposure in microgravity aboard orbital space station MIR. During that time, the body weight of three female quails was decreased from 151 to $96 \mathrm{~g}$ (S abo et al. 1992). Also, the body weight of 2-3-day and 4-5-day-old quail chicks hatched and kept in weightlessness was reduced by $26-30 \%$ compared to body weight of control birds (Dadasheva et al. 2001). In adult rats, a significant effect of gravitational unloading was observed on motor performance (Kawano et al. 2000). Similarly, the body and hindlimb muscle weights of rats were significantly lower after 9 weeks of hindlimb-unloading than in the age-matched weight-bearing controls (Ohira et al. 2002).

Although the spaceflight and hindlimb suspension induced also muscle atrophy in both human and adult animals (Ohira et al. 1992; 1999), the data from the current study may suggest that hypodynamy in rapidly growing juvenile Japanese quails does not cause atrophy, but inhibits or depresses growth rate.

In summary, this report is the first study to examine the effects of simulated microgravity on the growth of Japanese quail from day 2 after hatching to 56 days of age. The present results indicate that simulated microgravity has a significant impact on the growth and development of quail chicks. Hence, this data may be useful for understanding quail ontogeny during exposure to altered gravitation in conditions of a real space flight. However, for correct evaluation of our results, it would be necessary to carry out a similar experiment in the weightlessness environment.

\section{Rast kurčiat prepelice japonskej v podmienkach simulovaného beztiažového stavu}

V laboratórnych podmienkach sa beztiažový stav simuluje prostredníctvom metódy hypodynamie. Cielom tejto práce bolo zhodnotit vplyvy hypodynamie na celkový telesný rast a rast pravej nohy kurčiat prepelice japonskej (samičieho pohlavia) odchovávaných v týchto podmienkach od 2. dňa po vyliahnutí do veku 56 dní. Z tohto dôvodu bola v týždenných intervaloch zaznamenávaná živá hmotnost', spotreba a konverzia krmiva, ako aj dížka femuru, tibiotarsu a tarsometatarsu.

Vplyv hypodynamie na sledované parametre sliepočiek prepelice japonskej bol významný $(p<0,001)$. Priemerná živá hmotnosṫ zvierat pokusnej skupiny po 56 dňoch hypodynamie bola o 34 \% nižšia ako hmotnost' vekovo zhodnej kontroly. Spotreba krmiva narastala s vekom u obidvoch skupín, avšak u prepelíc v hypodynamii bola približne o 17 \% nižšia. Taktiež konverzia krmiva pokusných zvierat bola ovplyvnená až do 42 dní ich veku, s výnimkou 14 dní. Velkosṫ femuru hypodynamickej skupiny bola o $0,7 \mathrm{~mm}$ menšia ako kontroly vo veku 56 dní. Tibiotarsus a tarsometatarsus prepelíc v hypodynamii boli na konci pokusu kratšie o 4,41 a $3,35 \mathrm{~mm}$.

Výsledky ukázali, že kurčatá prepelice japonskej sú schopné rásṫ a vyvíjat sa $\mathrm{v}$ podmienkach simulovaného beztiažového stavu. Tento poznatok je dôležitý $\mathrm{k}$ tomu, aby 
sa o uskutočnení podobného experimentu mohlo uvažovat aj $\mathrm{v}$ prostredí reálneho beztiažového stavu.

\section{Acknowledgement}

This work was supported by the Grant Agency for Science of Slovak Republic, VEGA grant No. 2/3046/23.

\section{References}

AGGREY, SE 2003: Dynamics of relative growth rate in Japanese quail lines divergently selected for growth and their control. Growth Dev Aging 67: 47-54

ALI, MF, GODFREY, EF 1970: The relationship between embryonic and postnatal growth in Japanese quail. Poult Sci 49: $320-321$

BOĎA, K, SABO, V, JURÁNI, M, GURYEVA, TS, KOČIŠOVÁ, J, KOŠŤÁL, L, LAUKOVÁ, A, DADASHEVA, OA 1992: Embryonic development and behaviour of Japanese quail exposed to microgravity. Acta Vet Brno 61: 99-107

DADASHEVA, OA, GURYEVA, TS, SABO, V, BOĎA, K, KOČIŠOVÁ, J 2001: Research into morphology of Japanese quails hatched under conditions of microgravity. Folia Vet 45 (Suppl 1): S12-S16

GURYEVA, TS, DADASHEVA, OA, MELESHKO, GI, SHEPELEV, YeYa, BODA, K, SABO,V 1993: The quail embryonic development under the conditions of weightlessness. Acta Vet Brno 62 (Suppl 6): S25-S30

GURYEVA, TS, MEDNIKOVA, EI, DADASHEVA, OA, POVALKO, NB 1998: The musculoskeletal apparatus of Japanese quail during hypodynamy. Folia Vet 42 (Suppl): S37-S39

HYANKOVA, L, KNIZETOVA, H, DEDKOVA, L, HORT, J 2001: Divergent selection for shape of growth curve in Japanese quail. 1. Responses in growth parameters and food conversion. Br Poult Sci 42: 2001

JURÁNI, M, VÝBOH, P, LAMOŠOVÁ, D, BAROŠKOVÁ, Ž, SOMOGYIOVÁ, E, BOĎA, K, GAŽO, M 1983: The effect of a 90-day hypodynamy on the neurohumoral system, egg laying and metabolism of proteins in Japanese quail. Physiologist 26 (Suppl 6): 145-148

KAWANO, F, NOMURA, T, KANG, MS, LEE, JH, HAN, EY, CHIU, YC, SATO, Y, ISHIHARA, A, OHIRA, Y 2000: Effects of 9 weeks of hindlimb unloading on motor performances in adult rats. J Grav Physiol 7: 115-116

KOČIŠOVÁ, J, SABO, V, TOMAJKOVÁ, E, BOĎA, K 1998: Morphological changes in m. gastrocnemius during hypodynamy. Folia Vet 42 (Suppl): S41-S44

LASKEY, JW, EDENS, FW 1985: Hatch weight selection: effect on post-hatch growth in the Japanese quail (Coturnix coturnix japonica). Comp Biochem Physiol A 82: 101-104

LILJA, C 1982: Postnatal growth and organ development in the quail (Coturnix coturnix japonica). Growth 46: $88-99$

LILJA, C 1983: A comparative study of postnatal growth and organ development in some species of birds. Growth 47: 317-339

LILJA, C, MARKS, HL 1991: Change in organ growth pattern associated with long-term selection for high growth rate in quail. Growth Dev Aging 55: 219-224

LILJA, C, SPERBER, I, MARKS, HL 1985: Postnatal growth and organ development in Japanese quail selected for high growth rate. Growth 49: 51-62

MARKS, HL 1978: Growth curve changes associated with long-term selection for body weight in Japanese quail. Growth 42: 129-140

OHIRA, Y, JIANG, B, ROY, RR, OGANOV, V, ILYINA-KAKUEVA, E, MARTIN, JF, EDGERTON, VR 1992: Rat soleus muscle fiber responses to 14 days of spaceflight and hindlimb suspension. J Appl Physiol 73 (Suppl): 51S-57S

OHIRA, Y, YOSHINAGA, T, OHARA, M, NONAKA, I, YOSHIOKA, T, YAMASHITA-GOTO, K, SHENKMAN, BS, KOZLOVSKAYA, IB, ROY, RR, EDGERTON, VR 1999: Myonuclear domain and myosin phenotype in human soleus after bed rest with or without loading. J Appl Physiol 87: 1776-1785

OHIRA, Y, NOMURA, T, KAWANO, F, SATO, Y, ISHIHARA, A, NONAKA, I 2002: Effects of nine weeks of unloading on neuromuscular activities in adult rats. J Grav Physiol 9: 49-59

POZSGAI, A, HIDEG, J, REMES, P, TOTH, E, DERENYI, E, PETER, I 1990: Urinary excretion of 3 metylhistidine in rats subjected to various forms of simulated weightlessness. In: Current Trends in Cosmic Biology and Medicine, Ed. by K. Boda, Vol. 1, Institute of Animal Biochemistry and Genetics, Slovak Academy of Sciences, Ivanka pri Dunaji, pp. 225-231 RICKLEFS, R 1979: Patterns of growth in birds. In: A comparative study of development in the starling, common tern and Japanese quail. The Auk, 96, pp. 10-30

SABO, V, BOĎ, K, GURYEVA, TS, DADASHEVA, OA 1992: Changes in the body and organ mass of Japanese quail after a 7-day exposure to microgravity. Acta Vet Brno 61: 109-113

SABO, V, CHRAPPA, V, BODA, K 1998: Effect of long-term (84-days) hypodynamy on the efficiency of Japanese quails. Folia Vet 42 (Suppl): S59-S61

SABO, V, BOĎA, K, GURYEVA, TS, DADASHEVA, OA, BELLA, I 2001: The study of postembryonic development of Japanese quail chicks under microgravity and load on the orbital station MIR. Folia Vet. 45 (Suppl 1): S9-S11 
ŠKROBÁNEK, P, HRANČOVÁ, M 2003: Adaptability of Japanese quail chicks to conditions of simulated weightlessness. Acta Vet Brno 72: 347-351

ŠKROBÁNEK, P, SABO, V, BOD̃A, K, BARANOVSKÁ, M, MRAVCOVÁ, I 2001: The capacity of Japanese quail hatchlings to adapt to hypodynamy. Folia Vet. 45 (Suppl 1): S69-S70 